\title{
Cooperation under conflict: participatory hydrological modeling for science policy dialogues in the Aculeo Lake
}

\author{
Anahi Ocampo-Melgar ${ }^{1}$, Pilar Barría ${ }^{1,2}$, Cristián Chadwick $^{3}$, Cesar Rivas $^{1}$ \\ 1 Facultad de Ciencias Forestales y de la Conservación de la Naturaleza, Universidad de Chile, Santiago, Chile. \\ 3 Facultad de Ingeniería y Ciencias, Universidad Adolfo Ibáñez, Santiago, Chile.
}

Correspondence to: A. Ocampo-Melgar (anahi.ocampo10@gmail.com)

\begin{abstract}
Hydrological modeling tools can support collaborative decision processes by visually displaying hydrological systems connections, uncertainties and gaps, as well as conflicting preferences over water management strategies. Nevertheless, many challenges remain in the real application of these technical tools to successfully implement, capture, and communicate to nonexperts the complexities of coupled human hydrological systems and effectively support science policy dialogues. The disappearance of a $12 \mathrm{~km}^{2}$ lake in the Aculeo basin in Chile led to increasing socio environmental conflicts over the causes and effects of the water scarcity. A traditionally

15 WEAP based hydrological model study aiming to explore the causes of the lake desiccation, was transformed into a multiple question driven socio hydrological modeling process to help answer the diversity of questions instigating conflict. The surface aquifer hydrological model tested a subset of socially accepted management strategies under two climate change scenarios, showing that combining more low impact, but socially acceptable adaptation measures such as using the out of season irrigation surplus (March to May), improving irrigation efficiency for agriculture industry and decreasing the grass surface in new urbanizations, would allow to recover up to half the Lake water volume even under a pessimistic climate change scenario. As presented in this article, flexible approaches and research agendas could better support the exploration of synergies towards collaboration and production of useful and socially acceptable hydrological models and water management strategies.
\end{abstract}


Keywords: water scarcity, modeling, participation, transdisciplinary, conflict, socio hydrology.

\section{Introduction}

Sound science is necessary to support decision making where population, economic and climate change have aggravated conflicts over water (Poff et al., 2016, 2003). However, on top of the scientific uncertainties impacting water stationarity (Galloway, 2011; Kiparsky et al., 2012; Milly et al., 2008), societal complexities make water related problems "wicked", given their competing and mutually exclusive deep human values and aspirations that are not resolved with technical and economical strategies (Nie, 2010). Addressing water problems from a technocratic and solely governance point of views, is to disregard the political and transformative power of water (Boelens et al., 2016; Melsen et al., 2018). In this challenge, the hydrological scientific community is searching for approaches to better show the social ecological interconnections (Mauser et al., 2013; McMillan et al., 2016; Salter et al., 2010), and the different types of knowledges that can contribute to a science policy dialogue (Nardi et al., 2021).

However, science policy interactions and processes, are neither simple nor straightforward (Hegger et al., 2012; Scott et al., 2012). First, science society collaborations require non-scientists with a deeper understanding of the complex interactions and behavior between the natural, economic and social processes (Pahl-Wostl, 2006), and a better understanding of the uncertainties and risks attached to the scientific process (Jasanoff, 2003; Röckmann et al., 2012), a requirement that has been found to be difficult to address by scientists (Kahan, 2010; Nisbet, 2009; Somerville et al., 2011), as well as a main barrier to collaborative efforts towards engaging diverse stakeholders in decision making (Larson et al., 2009). Then, science society collaboration requires scientists that can not only adjust the scientific process and results to different timeframes, and different needs of science policy interactions (Rice et al., 2009), but also recognize the deeply political impact of communicating scientific results (Budds, 2008; Dabelko, 2005).

50 In this science policy challenge, there is an academic and practical need for a diversity of 
approaches and methods to better support transdisciplinary communication and understanding between scientists and non-scientists. These approaches should ideally facilitate transdisciplinary efforts, in at least two aspects: i) the decision context: support communicating, structuring and displaying complex system information and connections (Arvai, 2003; Rowe and Frewer, 2000;

55 Wilson and Arvai, 2006), ii) the decision result: clarifying the role of stakeholders and society within the decision context, and the influence of that decision in that context (Gorddard et al., 2016). Both the process and the result are connected, as the a legitimate result is part of a credible and salient science collaboration in decision making (Cash and Clark, 2001). An structured decision processes can help stakeholders understand the environmental policy link of their choices (Brewer and Stern, 2005), while aid in the co-creation of knowledge and boundary objects, an abstract element or tool that can be used across knowledge domains, which may also serve as a means of transdisciplinary communication and bring closer conflicting visions (Fuller, 2009).

As we present here, information and communication technology tools, such as hydrological modeling and simulation softwares, could represent both a structured process and a boundary object to support understanding and social learning in water resources management. Despite their usually broad scale application, rigidity and engineering purposes, such tools could support in both the challenges of decision context and process mentioned earlier by: 1) visually displaying hydrological systems connections, as well as the uncertainties and knowledge gaps in the information; 2) clarifying and debating the conflicting preferences of the affected population in the evaluated water management strategies. However, the level of involvement of participants in the design and testing of hydrological models can greatly vary according to the specific characteristics and objectives of the stakeholders (Voinov and Gaddis, 2008), and impact the sense of co-authorship over the product and results of this collaboration (Basco-Carrera et al., 2017).

An example of where neither science by itself, nor public participation alone were enough to properly address the conflicting views of a water related wicked problem, is the Aculeo Lake desiccation in Chile. The drying of the Aculeo Lake, a $12 \mathrm{~km}^{2}$ water body, has been an internationally iconic prove of the water problems that is facing Chile (Barría et al., 2021). The 
photographs showing the before/after outcome, as well as of trucks distributing water, were used in diverse national and international media to discuss climate change and water governance in Chile $^{1}$. To respond to the water scarcity, and specifically the Aculeo Lake desiccation causes and possible solutions questions, it was necessary to develop a basic surface-aquifer hydrological model. The hydrological modeling study collided and strongly collaborated with a participatory process called the Voluntary Agreement for Watershed Management (AVGC in Spanish) - a dialogue process usually implemented by the Chilean Government in the context of Climate Change international agreements. Consequently, the traditional hydrological modeling process had to be transformed into a collaborative modeling process in order to confront and include as most opposed views as possible.

In this article, the modeling of strategies and results are described and explored. Additionally, insights from behind the scenes during the Aculeo Lake modeling process are presented as a

90 guideline for participatory modeling and transdisciplinary efforts in contexts of high conflict and poor information on the hydrological system. This is important in Chile, as the combination of surface and underground hydrological modeling software described in this article is implemented in National watershed management to develop the first set of Strategic Planning at the Watershed Level throughout Chile. Therefore, the importance of this study to shows how to use this tool to work towards effective collaboration and mutual learning, while disseminate their usefulness for transdisciplinarity in hydrological and water resources management.

\section{The Aculeo water crisis}

The Aculeo Lake basin is a $200 \mathrm{Km}^{2}$ sub basin of the Maipo River in the Metropolitan Region, Central Chile (Figure 1), a mainly agricultural zone $50 \mathrm{~km}$ south from Santiago, the capital of

Chile, but also, was one of the most iconic touristic hotspots of the Metropolitan region of the

\footnotetext{
${ }^{1}$ AFP. Drought wipes popular Chilean lake from the map. In: https://www.youtube.com/watch?v=ylnrj_cSB5Y; Aljazeera. Chile suffers the worst drought in 60 years. In: https://www.youtube.com/watch?v=qO_YMvUfW-g
} 
country. Runoff from several creeks from the upper basin (2000 m.a.s.1.) flow into the Aculeo Lake located in the middle of the valley. Around $526 \mathrm{~mm}$ of rainfall is the annual average (data from 1960-2016), 94\% of which is received in autumn-winter (April to September) and 6\% is spring-summer rain (October to March). This is a heavily intervened basin, as many agricultural basins in Central Chile (more on this below). The lake should naturally drain to the Aculeo creek (also called Santa Marta or Santa María) towards the Huiticalan creek, but a small detour infrastructure keeps water from naturally flowing.
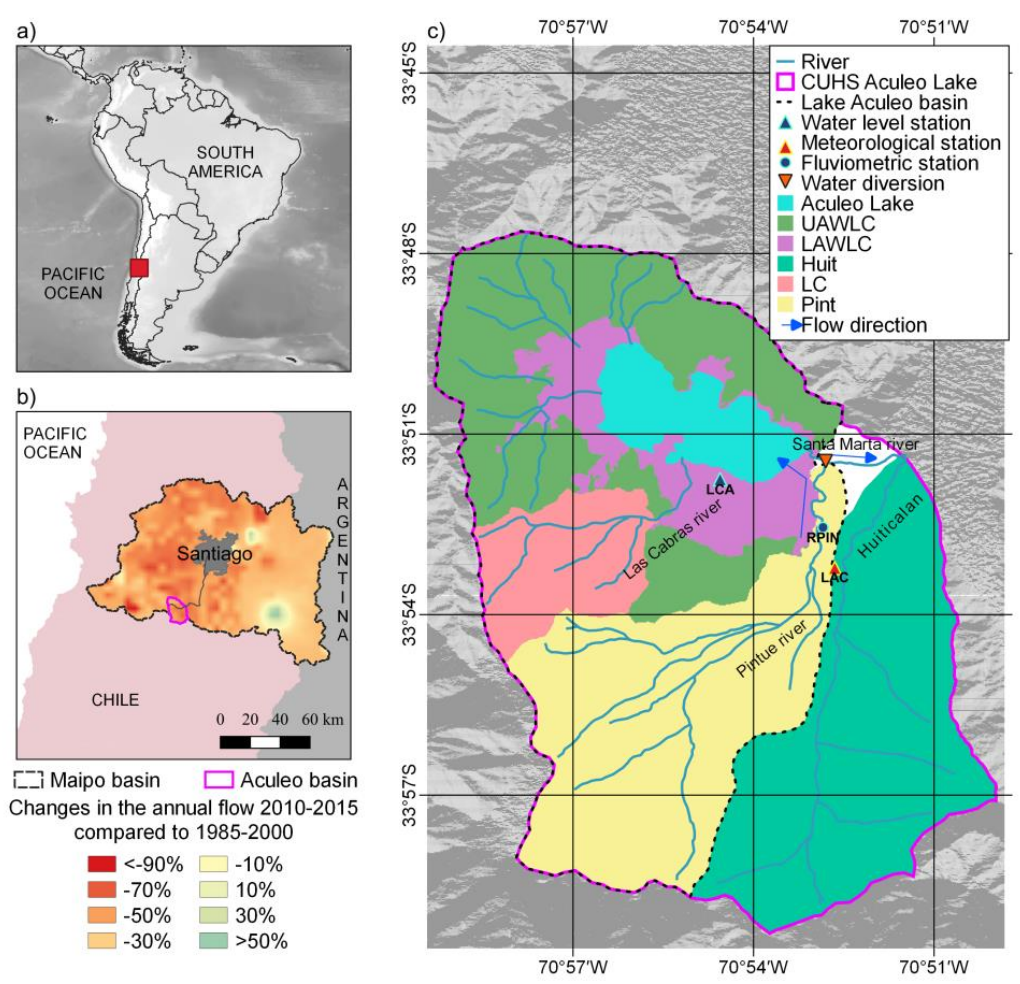

Figure 1. The Aculeo Basin located in central Chile near the capital Santiago (left panel), and main sub-basins modeled in WEAP (right panel). 
Agriculture and livestock have been the main productive activities in the Aculeo valley, since 1660 when this was a private large state (hacienda). During this time, the Aculeo Lake basin also went through a physical transformation from a natural basin to an anthropogenic watershed with a series of channelization for different productive activities. The first Agrarian Reform in 1962 Law No.

115 15,020, redistributed land among peasants until the military coup of 1973 (Bellisario, 2007; Órdenes and Díaz-Diego, 2018). During the military government, the 1981 Water code transformed water in shares to be transacted in a free market (Bauer, 2004; Madaleno and Gurovich, 2007), given by the General Water Directorate (DGA) to anyone who asks as long as there is availability. The 1981 Water Code had slight adjustments in 2005 with the establishment of water ecological flow restriction for new water rights, a fee in the case of non-use of water rights and the obligation to report transactions on water rights, but its essence is still primarily market based.

The Aculeo Lake drying process started in 2010, until it went completely dry in 2018. The megadrought (Garreaud et al., 2017, 2019), has manifested as a sequence of years with 25\% to 45\% precipitations deficit affecting Central Chile since 2010 in terms of reduction in streamflows and increasing evapotranspiration processes. Nevertheless, several uncertainties remained related with the human management factor in the water scarcity. In this regard a hydrological modeling study was commissioned to explore the potential causes of the lake desiccation (Barría et al., 2021). The hydrological study used a surface (WEAP software) and groundwater (MODFLOW software) hydrological model to explore possible solutions to restore the Aculeo Lake or alleviate the water scarcity.

As it should be expected, the lake desiccation exacerbated conflicts among users, including additional indirect conflicts, such as livestock wandering and later dying because of the lack of water, creating problems for ecosystems and later major sanitary issues. This ecological and social problem, led the DGA to announce in 2018 a set of measures to reverse the situation of the lake, ensure human consumption for the population living nearby, and strengthen the monitoring and control of water extractions. Following, the Sustainability and Climate Change Agency (ASCC in 
Spanish) was mandated by the Environmental Ministry to work on an AVGC. The AVGC is a process in which different private and public organizations (including academia ${ }^{2}$ ) voluntarily work to identify different actions and strategies in which to collaborate to address a basin challenge (e.g. a private company may support a civil organization to find funds for water conservation). Water scarcity was one of those problems in discussion, which also further pushed interaction with the hydrological modeling study. Although these two processes were designed to be implemented in parallel, giving the level of conflict and large number of uncertainties, we saw an opportunity actively participate in the AVGC process and move towards a more transdisciplinary hydrological modeling.

\section{Data and methods}

\subsection{WEAP hydrological model}

The surface-groundwater model used for the hydrological balance analysis was the Water 150 Evaluation and Planning System (WEAP) (Yates et al., 2005a, 2005b). WEAP is a semi distributed hydrological modeling software tool that uses nodes and links in a graphical platform, allowing to incorporate inputs (e.g. climatic information, land use/land cover) and obtain outputs in a watershed (e.g. evaporation, infiltration, extractions), to estimate the water balance and simulate different possible scenarios. This system has been used in participatory processes to study climate change adaption options (Bhave et al., 2014), ecosystem services assessment (Yates et al., 2005a) or the economic impact of water agricultural policies (Varela-Ortega et al., 2011). The aquifer and its connection to the lake and other catchments, is represented by a node that gathers its hydrogeological characteristics, analyzed as part of the hydrological study project (Barría et al., 2021).

\footnotetext{
${ }^{2}$ Authors of this study were also participants of the AVGC meetings, acting as potential academia partners for the resulting agreement.
} 
160 The development of the WEAP model, and the water balance is explained in detail in two technical reports (Barria et al. 2019, Bluedot, 2020), as well as in a peer-reviewed paper that explains the causes of the Aculeo Lake desiccation (Barría et al., 2021). To perform the water balance, the WEAP model uses as input data the historical configuration of the land use/land cover (LULC), and its changes, in addition to historical climatological information. Also, the hydrological modelers need to properly translate the conceptual understanding of the hydrology into the model.

Historical land use/land cover (LULC) was done for 2006, 2012 and 2018, three years in which good quality Landsat and Google Earth images were available. An unsupervised LULC classification of large extension such as native forest or shrublands was first conducted, followed by a photointerpretation of 2006, 2012 and 2018 Google Earth images to improve the classification of smaller agricultural and urban plots. Finally, a comparison and correction were performed using pictures of in-situ UAV (Unmanned Aerial Vehicle) flights for the year 2018, and information of local interviews for the years 2006, 2012, and 2018.

Local climate was characterized using monthly precipitation and temperature records since 1960 to date from the DGA-administered Laguna de Aculeo meteorological station $\left(33.89^{\circ} \mathrm{S}\right.$ and $71.45^{\circ} \mathrm{W}, 358$ m.a.s.1.). Due to the orographic enhancement of precipitation, the DGA topoclimatic maps (MOP, 2016) were used to obtain monthly precipitation and temperature data for the different elevation bands of the model (not shown). The WEAP model was evaluated using 2003-2009 monthly runoff records of the Pintue river station; administrated by the DGA, but currently suspended. Pintue river has a pluvial regime with maximum runoff during June, July and August

180 (Austral winter months) of about 1,463 1/s, with lack of base flow. Given the scarcity of runoff records, water levels recorded at the Laguna Aculeo en los Castaños station $\left(33.88^{\circ} \mathrm{S}\right.$ and $70.89^{\circ} \mathrm{W}$ ) were used estimate the Lake volumes in January 2006 and May 2013, and then calibrate the surface-groundwater balance model.

Hydrological modeling was very difficult given scarce information and inconsistencies between 
official and non-official information, therefore visits and interviews were used to collect, contrast and/or incorporate on the ground information to complement official sources. One of the main challenges, among many, was the short fluviometric records in the basin (i.e. less than seven years for only one station), the non-existence of previous detailed groundwater studies. For more details regarding the WEAP model construction, calibration, validation, the water balance and the aquifer information, we would like to refer the readers to Barria et al. (2019), Bluedot, (2020), and Barria et al., (2021).

\subsection{Iterative approach to hydrological modeling of the Aculeo basin}

Following the methods section is divided in two main moments that guided the modeling process: 1) discussions on the problem causes, and 2) discussion on the solutions. Although both questions are related, as the elimination of cause can be considered a solution, this article only expands in the participatory evaluation and hydrological simulation of solution strategies related with water management. Results from the climatic 'causes' (e.g. precipitation decrease due to megadrought) modeling process along with climate scenarios sensitivity analysis, are better described in Barria et al., (2021).

\subsubsection{Hydrological model construction}

In the line of the participatory modeling literature and the categories of participation by (BascoCarrera et al., 2017), the Aculeo Lake modeling followed a consultation during the modeling stage and a discussion during the scenario analysis, going back to a co-design to refine the model structure and input used in the modeling stage (Figure 2). Besides the basic elements of the hydrological model required by the modeling environment (e.g. Digital Elevation Model, inflows and outflows records, among others), the participation of this team as members in the discussions of the Voluntary Agreement group, resulted in a diversification of questions and possibilities for the parallel modeling process. On one hand, these instances were used by the modelers (this article authors) to identify additionally questions that were pressing and causing suspicion and conflict 
210 among participants, such as belief that water diversions upstream was not only illegal, but also causing the lake desiccation. Second, these instances were also used by stakeholders to question and challenge the accuracy and validity of the hydrological model being constructed, which in turn forced the modeling team to challenge the official information and search for alternatives sources and approaches to find answers, such as the official versus the real number of water wells. In this 215 process, contrasting opinions on both the causes of the water scarcity and the need to rehabilitate the Lake hinted at the level of underlying tension in this community (Ocampo-Melgar et al., 2021). Contrary to Bhave et al. (2014) where the objective was to evaluate alternatives, in this project the larger effort was to understand the hydrology to construct the model to evaluate causes of the water scarcity. Modeling water management alternatives was a necessary addition after constructing the model, given the level of conflict and scientific uncertainties that both teams (AVGC and hydrological modeling) encountered when exploring collaboration towards facing water challenges. Voluntary project participation in those collaborative meetings were then, a mean to refine the model, but also to combine local with scientific knowledge to corroborate that the model was answering the right and required questions for the collaboration endeavor. The iterative interactions were essential to co-produce a hydrological model and list of potential water management strategies inspired in the continuous stakeholders' questions and local knowledge, as well as critical questioning to the hydrological tool and modeling process as a political and decision making instrument.

Finally, to evaluate the sustainability of the strategies, a business as usual climate change scenario (Representative Concentration Pathway RCP 8.5, Van Vuuren et al., 2011) and a moderate scenario (RCP 4.5) were also considered in the water balance simulations. To assess the effectiveness of these strategies, a reference scenario, without considering them (without management strategies) under climate change was also implemented. 


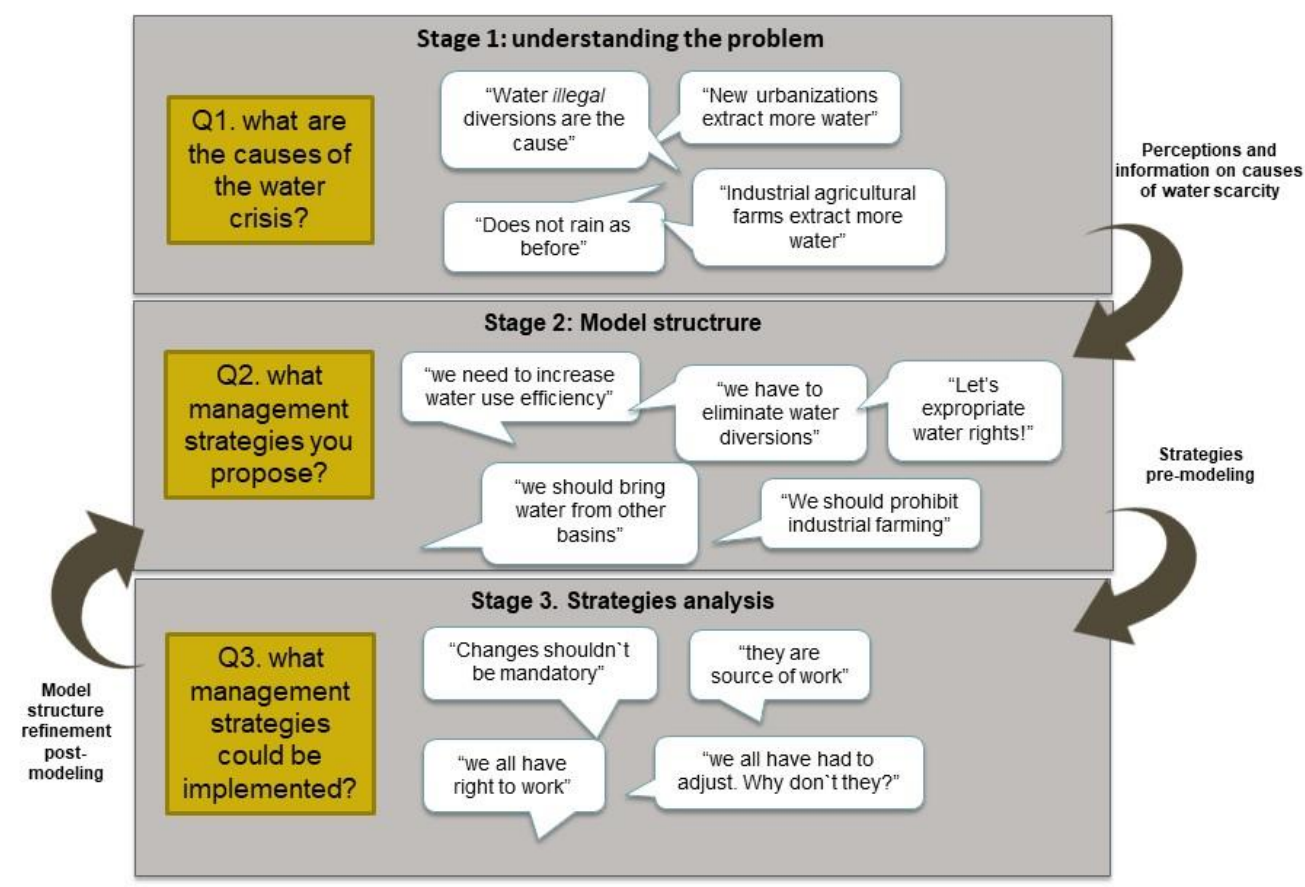

235 Figure 2. Main questions and iterative science society stages that fed the modeling process in terms of design, but also in model resolution and critical inquiry of information gaps.

\subsubsection{What management strategies could alleviate the crisis?}

As the hydrological model structure was being built with input from the stakeholders, a participatory evaluation of the different management strategies that could reduce the water balance

240 deficit was conducted. A list of eight water management strategies (e.g. water use by the agricultural sector), as well as four institutional support ideas management strategies were collected from the AVGC debates and extreme positions presented by the different stakeholders. Even though some of these "solutions" did not have a legal, nor social support or possibility of 
being implemented, it was decided to let the stakeholders consider their pertinence. This list was presented to 25 individuals from nine stakeholders groups participating in the AVGC process (Table 1) to elicit their interest or concerns about the strategies (Table 2). During these interviews, stakeholders were requested to comment and suggest changes, as well as to give a 1-3 value to each idea, where 1 was a very bad idea, 2 an acceptable idea, and 3 an excellent idea. Variations and considerations on each ranking were also gathered to make sure the wording of each strategy was understood.

Table 1. Stakeholder groups interviewed in the Aculeo Lake basin.

\begin{tabular}{|c|c|}
\hline Stakeholder group & Description and water use source \\
\hline $\begin{array}{l}\text { Rural Potable Water Association } \\
\text { (APR in Spanish) }\end{array}$ & $\begin{array}{l}\text { Group of water shares owners that extract, distribute and, in some cases, } \\
\text { treat water in rural areas. These organizations, under the 20,998/2016 } \\
\text { are non-profit. According to a new law from November 2020, they will } \\
\text { have to become a Service with different norms and obligations (still in } \\
\text { process). There are two APR near the lake, distributing superficial and } \\
\text { underground water to over } 400 \text { riverine families. }\end{array}$ \\
\hline Medium size farm owners & $\begin{array}{l}\text { Farmer owning land with over } 12 \text { ha of basic irrigation requirements } \\
\text { (National Irrigation Commission, CNR in Spanish). Medium size } \\
\text { farmers in Aculeo are located in the mid and upper basin, mainly } \\
\text { produce export goods (such as cherry, grapes, nuts, and other fruits), } \\
\text { have drip irrigation, and may be organized in channel associations } \\
\text { (asociación de canalistas), legal entity in the Chilean Water Code for } \\
\text { the management of water infrastructure in a basin. }\end{array}$ \\
\hline Small size farm owners & $\begin{array}{l}\text { Farms that have less than } 12 \text { ha of irrigation land (CNR and INDAP } \\
\text { (Institute of Agricultural Development classification), located in } \\
\text { different sectors of the basin, mainly producing cereals and horticulture } \\
\text { for the local market under surface/gravity irrigation, and organized in } \\
\text { irrigation groups or water communities (Comunidad de agua) around a }\end{array}$ \\
\hline
\end{tabular}


Tourism camp sites owners

Livestock association members

New building sector
Private areas around the lake rented for camping and recreation. Water for human consumption, as for gardening irrigation and pools came from private wells, as they are not usually associated with the APRs.

Arrieros or transhumance livestock producers (an old tradition in mountain ranges following the seasonal change of pasture and water). In Aculeo, as in many parts in Chile, arrieros do not own water nor land, but pay an old "tribute" to landowner in the form of non-paid day of work per head of cattle passed through their land.

Organizations of either real state groups or new built areas ("condominium" of second homeowners that populated areas around the lake). These organizations have their private anonymous societies for water distribution that own underground water shares. However, the lake was important for recreational activities and affected their real state value.

\subsubsection{What is the impact of those solutions in the Aculeo water scarcity?}

Once an initial hydrological structure for the Aculeo basin was complete (inflows and outflows), 255 a subset of the "Action/Strategies" presented in Table 2, were simulated in the WEAP Aculeo Basin Model:

- Action 5. Agricultural irrigation efficiency: The improvements in agricultural water efficiency is commonly used in Chile to increase irrigation area. The strategy here is to increase water efficiency, but without increasing agricultural area. The interviews allowed to corroborate that industrial agriculture already has high irrigation efficiency, but there still are important amounts of annual crops with water efficiencies of $50 \%$. Two scenarios were simulated in WEAP, Scenario 1 increased the water efficiency of annual crop to $70 \%$, 
while Scenario 2 increases to $85 \%$.

- Action 6. Rural house grass gardens reduction: An increase of second home owners during the last decade coincided with the water crisis, generating discomfort and suspicion among traditional inhabitants about their preference for grass gardens, being the cause of the lake disappearance. Eliminating rural house gardens was perceived by the hydrological modeling group (the authors), as a good strategy before the interviews. However, people that used to work in other agricultural activities are currently working as gardeners, hence eliminating gardens might have a quite big impact. After interviews, simulation used recommendations by Bown and Fuentes. (2019), which is $20 \%$ of the gardens with grass, $30 \%$ the shrubs of intermediate consumption and $50 \%$ of the surface with cacti species, stones, or xerox type garden, with no irrigation. This scenario incorporates both the need to reduce water consumption and the peoples need of not eliminating grass due to the impact it may have to their jobs.

- Action 10. Elimination of water diversions: This watershed has a long history of occupation, which has resulted in numerous manmade water structures, some are not even known by its owner due to their antiquity. Historical aerial photography and legal information were analyzed on a specific manmade stream diversion channel up in basin that according to a conservation with a social movement, through those diversions some people had been stealing water from the watershed. Although from a water balance perspective the diversion (legal or not) is an extraction old enough to be considered, there were sensible tensions that needed an answer. The diversion channel was visited, followed by interviews with the Agriculture and Livestock Service and review of 1956 property documents borrowed from the Real State Conservative, confirming the legality of those water shares. Even though diversion was confirmed to be legal, and eliminating it means the expropriation of Water Use Shares (WUS), an extreme measure in Chile given that water shares are real state asset, the strategy was simulated to respond to stakeholders' concerns. This potential strategy considers the diversion of water not being used in some 
months of the year by other nearby basins (which would make it feasible without actually expropriating WUS) in two inflow scenarios, one with $700 \mathrm{l} / \mathrm{s}$ and the other with 1,000 1/s, from March to May. In fact, there is a project currently being under study called "Aguilino Chanal" that may have a similar goal.

295 Other strategies, although important to improve management, were not contributing in a significant way into the overall water budget (actions 1, 2, 3, 4, 12 in Table 2), or were not possible to simulate given the level of information needed (action 8). In other cases, actions were not simulated due to not acceptance by stakeholders. This was the case of industrial farming prohibition, which the majority of the interviews showed to be a none acceptable strategy, due to its economic impact.

\section{Results}

\subsection{Participatory evaluation of water balance strategies}

Individual interviews and group discussions with stakeholders showed that the most "extreme" solutions may not necessarily have the majority support, even without considering the possible legal and technical limitations. In Table 2, a summary of individual rates or evaluations of each strategy is presented.

Table 2. Assessment and general comments on the strategies or lines of action by the interviewees

\begin{tabular}{|l|l|c|l|}
\hline Action/strategy & General comments & $\begin{array}{c}\text { General } \\
\text { acceptance } \\
\text { (rate 2 or } \\
\mathbf{3} \text { ) }\end{array}$ & $\begin{array}{l}\text { General difficulty on } \\
\text { implementation }\end{array}$ \\
\hline $\begin{array}{l}\text { 1) Swap: water shares } \\
\text { exchange systems between } \\
\text { users }\end{array}$ & "It is a solidarity solution" & $100 \%$ & $\begin{array}{l}\text { Has been applied before in other } \\
\text { basins. Although it requires a legal } \\
\text { and mandatory water users' } \\
\text { agreements. }\end{array}$ \\
\hline
\end{tabular}




\begin{tabular}{|c|c|c|c|}
\hline $\begin{array}{l}\text { 2) Support for the Rural } \\
\text { Drinking Water } \\
\text { Organizations that provide } \\
\text { drinking water }\end{array}$ & $\begin{array}{l}\text { "It is necessary to avoid } \\
\text { another water crisis." }\end{array}$ & $100 \%$ & $\begin{array}{l}\text { There are institutional and } \\
\text { financial changes that have been } \\
\text { assessed for the State agency to } \\
\text { better support rural organizations }\end{array}$ \\
\hline $\begin{array}{l}\text { 3) Implementation of } \\
\text { underground Water } \\
\text { Communities (Comunidad } \\
\text { de Aguas Subterráneas } \\
\text { CASUB in Spanish) }\end{array}$ & $\begin{array}{l}\text { "It is necessary but does not } \\
\text { solve the illegal water } \\
\text { extractions problem." }\end{array}$ & $89 \%$ & $\begin{array}{l}\text { Is the formal organization to } \\
\text { manage aquifer water resource. } \\
\text { There are experiences in other } \\
\text { basins. While this project was } \\
\text { being conducted, the Water DGA } \\
\text { was starting conversations on this } \\
\text { line. }\end{array}$ \\
\hline $\begin{array}{l}\text { 4) General Water } \\
\text { Directorate (DGA) } \\
\text { strengthening }\end{array}$ & $\begin{array}{l}\text { "It is necessary, but also to } \\
\text { define new and different roles } \\
\text { than only inspection and } \\
\text { fining." }\end{array}$ & $89 \%$ & $\begin{array}{l}\text { There are institutional and } \\
\text { financial changes that have been } \\
\text { assessed in different reports for the } \\
\text { DGA to better conduct their } \\
\text { supervision role in Chile. }\end{array}$ \\
\hline $\begin{array}{l}\text { 5) Agricultural water use } \\
\text { efficiency }\end{array}$ & $\begin{array}{l}\text { "It is necessary, although it } \\
\text { does not solve the problem of } \\
\text { those small agricultures who } \\
\text { quit, due to the drought." }\end{array}$ & $100 \%$ & $\begin{array}{lcr}\text { It requires } & \text { investment on } \\
\text { infrastructure } & \text { and human } \\
\text { capabilities. } & & \end{array}$ \\
\hline $\begin{array}{l}\text { 6) Urban water use } \\
\text { efficiency (rural house } \\
\text { grass gardens elimination) }\end{array}$ & $\begin{array}{l}\text { "It is necessary but should not } \\
\text { be mandatory nor extreme. } \\
\text { Better to support voluntarily } \\
\text { reductions as it will affect jobs } \\
\text { for local people." }\end{array}$ & $77 \%$ & $\begin{array}{l}\text { It has been applied voluntarily by } \\
\text { individuals, but never as a } \\
\text { Municipal regulation. }\end{array}$ \\
\hline $\begin{array}{l}\text { 7) Industrial farming } \\
\text { prohibition }\end{array}$ & $\begin{array}{l}\text { "This is a terrible idea that will } \\
\text { affect agricultural jobs." }\end{array}$ & $44 \%$ & $\begin{array}{l}\text { No precedents for this type of } \\
\text { measures. Except in cases where } \\
\text { the market forces a crop change } \\
\text { for economic reasons. }\end{array}$ \\
\hline $\begin{array}{l}\text { 8) Proration of water } \\
\text { shares between legal users }\end{array}$ & $\begin{array}{l}\text { "It is fair and necessary. } \\
\text { Although it does not consider } \\
\text { illegal water extractions." }\end{array}$ & $100 \%$ & $\begin{array}{l}\text { It is a strategy being used in } \\
\text { several basins in Chile to } \\
\text { exchange water between users } \\
\text { when one of them does not need it. }\end{array}$ \\
\hline
\end{tabular}

\footnotetext{
${ }^{3}$ This option was originally going to be simulated as complete elimination of grass. However, after the round of interviews (section 3.2.3), the strategy was implemented in the model as an alternative garden for semi-arid central Chile, which according to Bown and Fuentes (2019), water consumption can be reduced up to an $80 \%$ in the summer months, through changes in plant species and their distribution.
} 


\begin{tabular}{|c|c|c|c|}
\hline $\begin{array}{l}\text { 9) Intra basin transfer by } \\
\text { connecting water } \\
\text { diversions for human } \\
\text { consumption in critical } \\
\text { season }\end{array}$ & $\begin{array}{l}\text { "It is not a solution for human } \\
\text { consumption as it does not } \\
\text { have enough quality. Could be } \\
\text { a solution to have some water } \\
\text { in the lake." }\end{array}$ & $100 \%$ & $\begin{array}{l}\text { There is a project and different } \\
\text { ideas, but none has been applied } \\
\text { before. }\end{array}$ \\
\hline $\begin{array}{l}\text { 10) Elimination of water } \\
\text { diversions (buying water } \\
\text { shares) }\end{array}$ & $\begin{array}{l}\text { "It can be unconstitutional to } \\
\text { expropriate water shares. } \\
\text { Should only be bought and for } \\
\text { human consumption only." }\end{array}$ & $100 \%$ & $\begin{array}{l}\text { This type of strategy has been } \\
\text { carried out in severe cases of water } \\
\text { scarcity and overexploitation of } \\
\text { water bodies, where the State has } \\
\text { had to buy water shares to meet } \\
\text { conservation or drinking water } \\
\text { needs, as in the case of the Ligua- } \\
\text { Petorca basins. }\end{array}$ \\
\hline $\begin{array}{l}\text { 11) Water transfer from } \\
\text { other basins }\end{array}$ & $\begin{array}{l}\text { "It is the only solution for the } \\
\text { lake, but it can be very } \\
\text { conflictive as there are no } \\
\text { other basins nearby with extra } \\
\text { water." }\end{array}$ & $89 \%$ & $\begin{array}{l}\text { There are some small projects in } \\
\text { the same basin, but no transfers } \\
\text { from other basins have been done } \\
\text { before. It will require large } \\
\text { agreements and if done it will have } \\
\text { social and environmental impacts. }\end{array}$ \\
\hline 12) Water reuse & $\begin{array}{l}\text { "It is a survival strategy that } \\
\text { has been already implemented } \\
\text { voluntarily; but does not solve } \\
\text { the problem." }\end{array}$ & $89 \%$ & $\begin{array}{l}\text { It requires financial support for } \\
\text { infrastructure and human training. }\end{array}$ \\
\hline
\end{tabular}

Additionally, to the percentage of low bad rating of some of the cases (e.g. water reuse), it is important to notice the representativeness of the stakeholder group that gave the low rating (e.g. may be an important economic sector), as well as the justifications given for their evaluation, as this information points out to aspects that could facilitate their implementation and avoid future conflict. This was the case of strategies that are implemented at a household scale, and therefore could require government support to alleviate the economic burden mentioned by citizens. At the 
315 same time, results showed that sometimes the most mentioned or publicized strategy while in the heat of conflict, may be recognize as a not very good option while discussed in private (e.g. industrial farming prohibition).

\subsection{Simulation of water balance strategies}

As described in section 3.1, a hydrological and a hydrogeological model were implemented to contribute with water balance information under different water management scenarios (Barria et al., 2021). Although there are 12 strategies gathered and evaluated (Table 2) during the participatory activities, only three of them are directly related to the water balance of the basin and could be modelled by the WEAP tool. Therefore, according to section 3.2.3, the participatory modelling considers: 1) the diversion of water not being used for some months of the year by the agriculture users of the Aguilino Channel (Aguilino), 2) Agricultural irrigation efficiency, increasing the efficiency of annual crops from 50\% to $85 \%$, and 3) Rural house grass gardens reduction, implemented as follow: $20 \%$ of the gardens with grass, $30 \%$ the shrubs of intermediate consumption and $50 \%$ of the surface with cacti species, stones, or xerox type garden, with no irrigation.

330 Figure 3 shows the lake water volume simulated under the historical, and climate change scenario as a result of the water balance of the basin. We used approximately 100 general climate models (GCMs) simulations from 30 models, under the RCP 4.5 and RCP8.5 scenarios (Van Vuuren et al., 2011), which were bias corrected using the Quantile Delta Mapping method (QDM, Cannon et al., 2015).

335 According to the simulations, by implementing the three adaptation measures under the historical climate ("Hist. adapt.", panels a, b, e and f of Figure 3), the volume of the lake would increase to around $34 \mathrm{Mm}^{3}$ (56\% of the lake volume) during the Megadrought. Note that as presented by Barria et al. (2021), the Aculeo Lake is completely desiccated since year 2018.

The simulations under climate change projections reveal that there are significant differences on 
340 the simulated water volumes when comparing the "no adaptation" (solid lines panels a and b of Figure 3) against the "adaptation" scenarios (dotted lines panels a and b of Figure 3). Under both climate change scenarios, the effectiveness of the strategies is evident for the dry $15^{\text {th }}$ percentile, which generate an increase in 28.2 and $20.8 \mathrm{Mm}^{3}$ of the lake volume compared to the scenarios without the strategies, under the RCP4.5 and the RCP8.5 scenarios respectively.

345 Moreover, the average of the different GCMs simulations (50 $50^{\text {th }}$ percentile) also shows large differences in the lake volume by including or not the strategies, with differences that fluctuates between 10.2 and $39.8 \mathrm{Mm}^{3}$ under the RCP4.5 and the RCP8.5 scenarios respectively, for the 2050-2100 period. Finally, the simulations for the last 30-years of the century under the severe climate change scenario, indicate that by implementing the three adaptation measures, half of the time, the lake would have $\sim 50 \mathrm{Mm}^{3}$.

Comparatively, although the three strategies contribute to the water balance, as presented in panels c) and d) of Figure 3, the linkage to agricultural channel adaptation measure, has the largest contribution to the lake water volumes under the climatic scenario. Among the three strategies, the contribution of the Aguilino for the 2050-2100 period under the RCP8.5 scenario, represents about $83 \%$ of the increase in the water volume, which is around ten times more than the contribution of the agricultural water use efficiency and the garden water use efficiency.

Although the two strategies oriented to improve the irrigation efficiency in the basin have a comparatively lower impact on the water balance at the basin scale, they can be part of a combination of strategies socially accepted by the stakeholders proved by the high ranking obtained, which could contribute to increase awareness of the complex water scarcity problem and to develop preparedness under climate change and its impacts. 

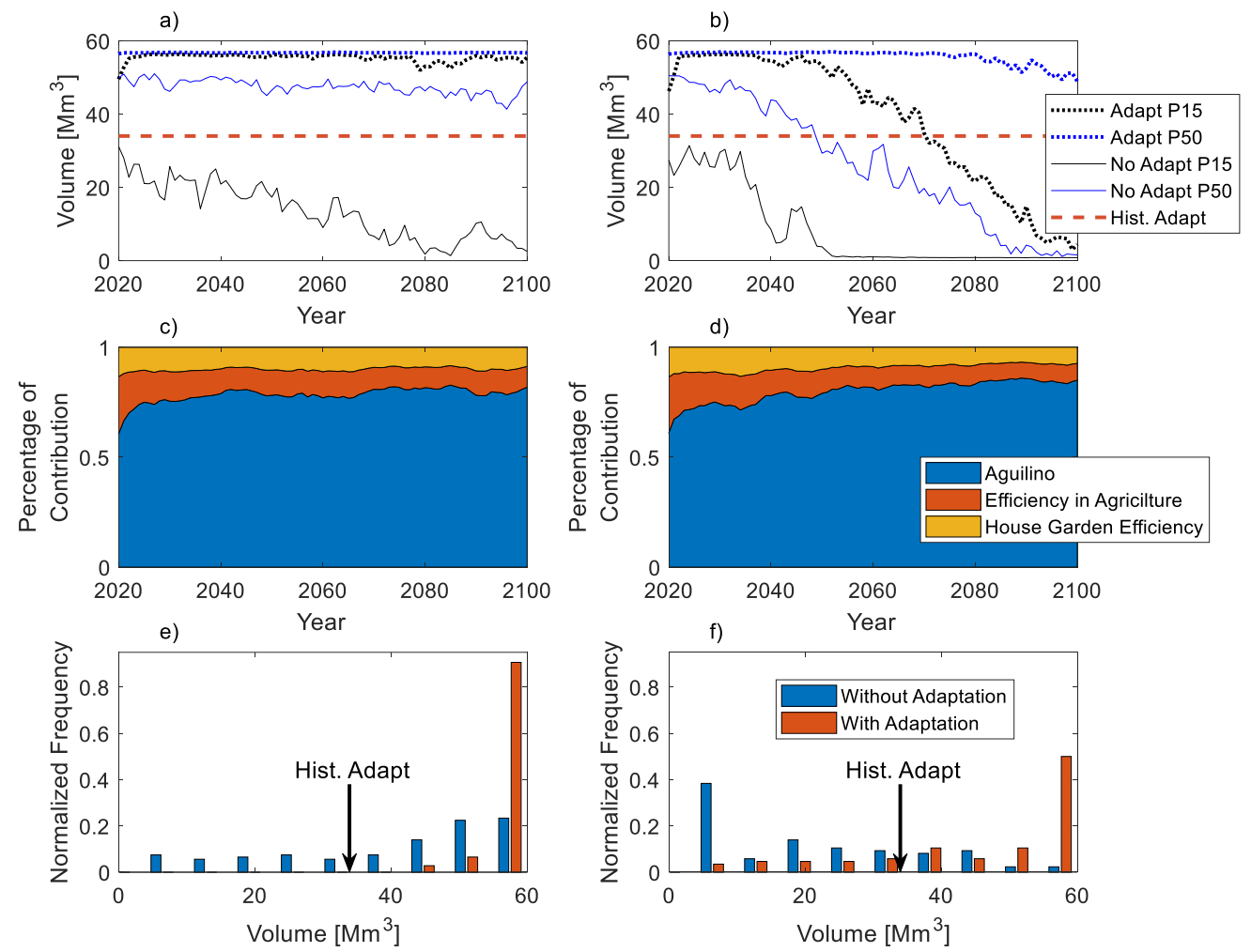

Figure 3. WEAP model water balance results under the combination of strategies; a) annual lake water volume simulated under the RCP4.5 scenario, b) same as "a)" but under RCP8.5 scenario, c) projected percentage of contribution of each strategy under the RCP 4.5 scenario, d) same as "c)" but under RCP8.5 scenario , e) normalized water volume frequency using different GCMs simulations on the period 2071-2100 under the RCP4.5 scenario, f) same as "e)" but under RCP8.5 scenario.

\section{Discussion}

These results highlight the importance of the participation in the modelling process, as they 
allowed for the identification of a combination of strategies that are of moderate impact, but of higher local acceptability than the large structural options. On the contrary, a solely top-down hydrological modeling would not have considered less efficient solutions, due to their relative more moderate impact in terms of the lake. From this experience, we have insights for science society initiatives involving hydrological modeling under limited information, and when underlying conflicts may demand a more collaborative process:

a. Addressing the right questions: Co-producing knowledge can help scientists to understand how their science could be more useful to respond stakeholders' needs to different decision scales (Corburn, 2003). The participatory modeling of the Aculeo basin showed that there is important information that can be extracted from local users to improve model accuracy and usefulness. For example, the Aculeo process showed that information (in this cases strategies preferences) obtained by individual interviews result very different than group conversations when discussion are used to show power over other stakeholders, while in individual conversations, stakeholders may smooth their comments. However, there is also a large chance of finding very different and contradicting information that is impossible to contrast, such as when there is a fine legal interpretation in between, or where there are no possibilities to confront the reality due to lack of data or time and funds constraints.

b. Managing uncertainties: For some authors, the process of making the uncertainty transparent weakens the model usefulness and creates misunderstanding between scientists and non-scientists (Hisschemöller et al., 2001; Webler et al., 2011). In our experience, it is better to discuss uncertainties as early as possible, as assumptions and information gaps will show eventually. Including local decisionmakers in the process of finding alternative solutions to those gaps may help empower them and make them participant of the modeling. As proposed by many authors before, complex problems where there is a high uncertainty in knowledge, distribution of power and ambivalent goals, are better approached through participatory and deliberative methods to discuss 
different possible narratives, than a single participatory modeling or top down policy approaches (Pellizzoni, 2012; Stirling, 2006; Wise et al., 2014).

c. Approaching positions: The use of hydrological models for supporting decision making in the Aculeo participatory process, showed that model acceptance was not related with model complexity. The acceptance and legitimacy of model increased once stakeholders noticed their knowledge and opinions were incorporated, which may or may not increase model complexity. When opinions are later confronted with the modeling results, an increased understanding may help bring closer originally opposite opinions, as it has been previously showed in deliberative processes that focus in understanding the problem and learning about different facts and values, while avoiding never ending discussion on the scientific uncertainty (Hermans et al., 2007). However, as we found, in some cases, when conflicts have surpassed a dialogue limit, and when many economic and political interests are involved, not even the best available science will make their positions closer.

d. The "neutral" role of the hydrological model: The model development and application should aim at supporting the conversation by showing different scenarios, while avoiding choosing a side. Nevertheless, as we found in this experience, maintaining neutrality is extremely difficult in situations of high conflict, especially in these times, as expressed by Pellizoni (2012), when science and technology are charged with growing social expectations, but are greeted with equally growing skepticism or hostility. Especially when the decision is over a politically contentious topic with uncertain science, there is the high probability that lack of credibility ("we don't believe this"), legitimacy ("the process has been corrupted"), and/or salience ("science answered the wrong question") of the results complicate the use of science for policy making (Cash et al., 2006). As Vogel et al. (2007) stated, "When scientists neglect-even if unintentionally - the political and strategic nature of scientific knowledge, and the political context in which it is produced, they can be faced with 
uncomfortable and challenging situations for whose navigation many are ill-equipped". Recognizing the political role of the hydrological model is part of making the process and us, as researchers, better at identifying better ways to address science society dialogues.

Main lessons from this research are summarized in a five steps participatory modeling engagement guideline to use when conflict and uncertainties are high. This is only a guideline for hydrological modelers, but not for the whole participatory process that should have a proper facilitation and different instances for dialogue and deliberation. As suggested by the literature 435 on participation and science production, this guideline aims at being as flexible, horizontal, transparent and open dialogue as possible, to co-produce a hydrological model that is accepted by the community, and later used for water resources management (Fraser et al., 2006; Garcia et al., 2016; Pellizzoni, 2012; Scott et al., 2012; Voinov and Gaddis, 2008).

- Step 1. Collect questions: In an initial stage, it is important to collect all pressing questions that stakeholders would like to have an answer and a discussion about the limitations and capabilities of the hydrological model. No questions should be eliminated due to an initial presumed lack of information. Only differentiate plausible from impossible questions to answer, to reduce the list to those that are related with a socio hydrological modeling, otherwise this type of participatory processes can become an endless process. This step is important to set the basis and limitations of hydrological modeling, but also to understand the context.

- Step 2. Divide questions on stages for the conceptual modeling development and for the simulation stage: remaining questions need to be grouped and organized in variables for the model, in terms of Causes, Links and Solutions. It is necessary to consider enough flexibility to be able to modify the conceptual model later, as other inquiries or questions can arise in the process that may change our conceptual view of the basin. In this step, 
regardless of the pressure, it is important to be unbiased and avoid rising expectations on the identification of "culprits", as this does not contribute to the necessary dialogue, nor represents the complexity of socio hydrological systems.

- Step 3. Evaluate information availability and quality: Once questions have been reduced and sorted, it is important to evaluate if there will be enough official or scientific information for the model. It is important to include stakeholders in this step by letting them know the information gaps, as well as the alternative methods and assumptions that have to be adopted to be able to proceed. This will help the hydrological model acceptance within the community, as well as helping in opening doors to alternative information that the community or other stakeholders may have that one did not originally knows, which helps both finding a technical solutions and the overall acceptance of the process.

- Step 4. Share model design and assumptions: Once data has been evaluated, there are assumptions to be made to proceed with the simulation process. Communicating scientific uncertainties and gaps can be used to test possibilities with them, for example, what scenarios should be tested and how. Claiming that there is not enough official information, will not be enough when conflict is high.

- Step 5. Communicating and discussing results: modeling results may not leave everybody happy, as there are conflicts underneath that an answer won't diffuse. As Goleman (1989) has discovered once an idea is conceived, of how the world works, one tends to incorporate information that validates that idea and discard contradictory information, hence people whose original ideas does not match the results will tend to discard your study. In this case, understanding the context, conflicts, perceptions and values involved are important to design the model, but also to find the most sensitive way to inform results (Abels, 2007). In many cases, modeling will be a bureaucratic step in a political decision defined earlier (as when modeling is used to finance a reservoir), then understanding the impact of our results is as important as being scientifically unbiased (Babidge, 2016; Budds, 2008). 


\section{Conclusions}

The participatory modeling implemented in the Aculeo basin was key to navigate throughout the complex situation, understand and recognize local actors' opinions, and concerns in the model structure, and in the identification of strategies. Specifically, the participatory identification and evaluation of strategies allowed to better adjust the hydrological model to answer questions that were causing suspicions and further conflicts among stakeholders. The same process was also important for the identification of a combination of strategies that were of moderate impact, but of higher local acceptability than the large structural options. The surface-groundwater model tested a subset of socially accepted management strategies under two climate change scenarios, showing that combining more low impact, but socially acceptable adaptation measures such as using the out of season irrigation surplus (March to May), improving irrigation efficiency for agriculture industry and decreasing the grass surface in new urbanizations, would allow to recover up to half the Lake water volume even under a pessimistic climate change scenario. Possibly, a solely topdown hydrological modeling would not have considered less efficient solutions, due to their moderate impact in recovering the Lake.

However, as the experience was not completely successful in terms of engagement, this article also shows that hydrological modeling requires now, more than ever, funding transdisciplinary approaches both in its construction, but also in its application as it is key to achieve boundary objects and credible, salient, and legitimate processes for decision making. As exposed in the Aculeo basin, especially when contentious water related conflicts are high and attribution of climate change impacts are uncertain, collaboration in the hydrological modeling process is key in finding management options that could contribute to both answering the problem, as well as to understand the conflict. This, however, may not be necessarily enough to reduce conflicting positions, that are constantly stirred according to personal interests. 


\section{Author contribution}

505 AOM, PB and CC, designed the study, contacted, and interviewed local stakeholders and participated in the voluntary agreement. AOM elaborated preliminary analysis of the interviews. CR gathered information for an economic and legal analysis of the strategies. PB and CC developed the hydrological model and simulated the strategies. AOM, PB, CC and CR discussed the results, $\mathrm{AOM}, \mathrm{PB}$ and $\mathrm{CC}$ prepared the manuscript.

510 Competing interest

The authors declare that they have no conflict of interest.

\section{Acknowledgements}

To the Regional Government of Santiago. Special acknowledgment to Bluedot Consulting for the hydrogeological study that complemented the WEAP model. More importantlyto all the

515 community and public services that engaged in the VBMA process. Data are publicly available from the Dirección General de Aguas, Chile (http://snia.dga.cl/BNAConsultas/reportes).

\section{Financial Support}

Regional Government of Santiago, project FIC-RM 2017 Code BIP 40002646-0 and FONDECYT Initiation Grant 11200027.

\section{References}

Abels, G.: Citizen Involvement in Public Policy-making: Does it Improve Democratic Legitimacy and Accountability? The Case of pTA, Interdiscip. Inf. Sci., 13(1), 103-116, doi:10.4036/iis.2007.103, 2007.

Arvai, J.: Using risk communication to disclose the outcome of a participatory decision-making process: Effects on the perceived acceptibility of risk-policy decisions, Risk Anal., 23(2), 281-289, 2003.

525 Babidge, S.: Contested value and an ethics of resources: Water, mining and indigenous people in the Atacama Desert, Chile, Aust. J. Anthropol., 27(1), 84-103, doi:10.1111/taja.12139, 2016. 
Barría, P., Chadwick, C., Ocampo-Melgar, A., Galleguillos, M., Garreaud, R., Díaz-Vasconcellos, R., Poblete, D., Rubio-Álvarez, E. and Poblete-Caballero, D.: Water management or megadrought: what caused the Chilean Aculeo Lake drying?, Reg. Environ. Chang., 21(1), doi:10.1007/s10113-021-01750-w, 2021. Barria P, Chadwick C, Ocampo-Melgar A, Diaz R, Galleguillos M, Poblete D (2019) Estudio de balance hídrico en la cuenca laguna de Aculeo. Proyecto FIC-R 2017 código BIP 40002646-0. Caracterización del consumo hídrico y del sistema hidrogeológico en la cuenca de Aculeo, determinación de posibles soluciones y campaña de educación Ambiental. Report for the Regional Government.doi

Basco-Carrera, L., Warren, A., van Beek, E., Jonoski, A. and Giardino, A.: Collaborative modelling or participatory modelling? A framework for water resources management, Environ. Model. Softw., 91, 95110, doi:10.1016/j.envsoft.2017.01.014, 2017.

Bauer, C. J.: Siren song: Chilean water law as a model for international reform, Resources for the Future., 2004.

Bellisario, A.: The Chilean agrarian transformation: Agrarian reform and capitalist "partial" counteragrarian reform, 1964-1980. Part 1: Reformism, socialism and free-market neoliberalism, J. Agrar. Chang., 7(1), 1-34, doi:10.1111/j.1471-0366.2007.00138.x, 2007.

Bhave, A. G., Mishra, A. and Raghuwanshi, N. S.: A combined bottom-up and top-down approach for assessment of climate change adaptation options, J. Hydrol., 518(PA), 150-161, doi:10.1016/j.jhydrol.2013.08.039, 2014.

545 Boelens, R., Hoogesteger, J., Swyngedouw, E., Vos, J. and Wester, P.: Hydrosocial territories: a political ecology perspective, Water Int., 41(1), 1-14, doi:10.1080/02508060.2016.1134898, 2016.

Bown, H.E. and Fuentes, J.P. Hacia la reducción del consumo de agua en áreas verdes urbanas en la Región Metropolitana. Santiago, Chile. 99 p. ISBN 978-956-404-628-0, 2021.

Brewer, G. D. G. and Stern, P. C.: Decision making for the environment: Social and behavioral science research priorities, Making, Environmental Decision Dimensions, Human Change, Global Isbn, Council Pdf, This Press, National Academies Academy, National. [online] Available from: http://books.google.com/books?hl=en\&lr=\&id=JeYKuQ13mCUC\&oi=fnd\&pg=PA1\&dq=Decision+maki ng+for+the+environment:+Social+and+behavioral+science+research+priorities\&ots=52In3d5qB4\&sig=a 
ONXSgXFOtnyqwdEXeGdWDC_ml0 (Accessed 9 December 2012), 2005.

Budds, J.: Whose Scarcity? The Hydrosocial Cycle and the Changing Waterscape of La Ligua River Basin, Chile, Contentious Geogr. Environ. Knowledge, Mean. scale, 59-78, 2008.

Cash, D. and Clark, W.: From science to policy: Assessing the assessment process. RWP01-045, edited by S. for A. R. and Training and C. for I. R. Assessment. [online] Available from: http://papers.ssrn.com/sol3/papers.cfm?abstract_id=295570 (Accessed 9 December 2012), 2001.

560 Cash, D. W., Borck, J. C. and Patt, A. G.: Countering the Loading-Dock Approach to Linking Science and Decision Making: Comparative Analysis of El Nino/Southern Oscillation (ENSO) Forecasting Systems, Sci. Technol. Human Values, 31(4), 465-494, doi:10.1177/0162243906287547, 2006.

Corburn, J.: Bringing Local Knowledge into Environmental Decision Making. Improving urban planning for communities at risk, J. Plan. Educ. Res., 22, 420-430, doi:10.1177/0739456X03253694, 2003.

Dabelko, G. D.: Speaking Their Language: How to Communicate Better with Policymakers and Opinion Shapers - and Why Academics Should Bother in the First Place, Int. Environ. Agreements Polit. Law Econ., 5(4), 381-386, doi:10.1007/s10784-005-8329-8, 2005.

Fraser, E. D. G., Dougill, A. J., Mabee, W. E., Reed, M. and McAlpine, P.: Bottom up and top down: analysis of participatory processes for sustainability indicator identification as a pathway to community 570 empowerment and sustainable environmental management., J. Environ. Manage., 78(2), 114-27, doi:10.1016/j.jenvman.2005.04.009, 2006.

Fuller, B. W.: Surprising cooperation despite apparently irreconcilable differences: Agricultural water use efficiency and CALFED, Environ. Sci. Policy, 12(6), 663-673, doi:10.1016/j.envsci.2009.03.004, 2009.

Galloway, G. E.: If Stationarity is Dead, What Do We Do Now?, JAWRA J. Am. Water Resour. Assoc., 47(3), 563-570, doi:10.1111/j.1752-1688.2011.00550.x, 2011.

Garcia, M., Portney, K. and Islam, S.: A question driven socio-hydrological modeling process, Hydrol. Earth Syst. Sci., 20(1), 73-92, doi:10.5194/hess-20-73-2016, 2016.

Garreaud, R. D., Alvarez-Garreton, C., Barichivich, J., Pablo Boisier, J., Christie, D., Galleguillos, M., LeQuesne, C., McPhee, J. and Zambrano-Bigiarini, M.: The 2010-2015 megadrought in central Chile: 
580 Impacts on regional hydroclimate and vegetation, Hydrol. Earth Syst. Sci., 21(12), 6307-6327, doi:10.5194/hess-21-6307-2017, 2017.

Garreaud, R. D., Boisier, J. P., Rondanelli, R., Montecinos, A., Sepúlveda, H. H. and Veloso-Aguila, D.: The Central Chile Mega Drought (2010-2018): A climate dynamics perspective, Int. J. Climatol., (June), 1-19, doi:10.1002/joc.6219, 2019.

585 Gorddard, R., Colloff, M. J., Wise, R. M., Ware, D. and Dunlop, M.: Values, rules and knowledge: Adaptation as change in the decision context, Environ. Sci. Policy, 57, 60-69, doi:10.1016/j.envsci.2015.12.004, 2016.

Hegger, D., Lamers, M., Van Zeijl-Rozema, A. and Dieperink, C.: Conceptualising joint knowledge production in regional climate change adaptation projects: Success conditions and levers for action, Environ. Sci. Policy, 18, 52-65, doi:10.1016/j.envsci.2012.01.002, 2012.

Hermans, C., Erickson, J., Noordewier, T., Sheldon, A. and Kline, M.: Collaborative environmental planning in river management: an application of multicriteria decision analysis in the White River Watershed in Vermont., J. Environ. Manage., 84(4), 534-46, doi:10.1016/j.jenvman.2006.07.013, 2007.

Hisschemöller, M., Tol, R. and Vellinga, P.: The relevance of participatory approaches in integrated environmental assessment, Integr. Assess., 2, 57-72 [online] Available from: http://www.springerlink.com/index/M134731236K82072.pdf (Accessed 10 December 2012), 2001.

Jasanoff, S.: Technologies of humility: citizen participation in governing science, Minerva, 41, 223-244, 2003.

Kahan, D.: Fixing the communications failure., Nature, 463(7279), 296-7, doi:10.1038/463296a, 2010.

600 Kiparsky, M., Milman, A. and Vicuña, S.: Climate and Water: Knowledge of Impacts to Action on Adaptation, Annu. Rev. Environ. Resour., 37(1), 163-194, doi:10.1146/annurev-environ-050311-093931, 2012 .

Larson, K. L., White, D. D., Gober, P., Harlan, S. and Wutich, a.: Divergent perspectives on water resource sustainability in a public-policy-science context, Environ. Sci. Policy, 12(7), 1012-1023, doi:10.1016/j.envsci.2009.07.012, 2009. 
Madaleno, I. M. and Gurovich, A.: Conflicting water usages in Northern Chile, Bol. La Asoc. Geogr. Esp., (45), 439-443, 2007.

Marttunen, M. and Suomalainen, M.: Participatory and Multiobjective Development of WaterCourse Regulation-Creation of Regulation Alternatives from Stakeholders ' Preferences, J. Multi-Criteria Decis.

Mauser, W., Klepper, G., Rice, M., Schmalzbauer, B. S., Hackmann, H., Leemans, R. and Moore, H.: Transdisciplinary global change research: The co-creation of knowledge for sustainability, Curr. Opin. Environ. Sustain., 5(3-4), 420-431, doi:10.1016/j.cosust.2013.07.001, 2013.

McMillan, H., Montanari, A., Cudennec, C., Savenije, H., Kreibich, H., Krueger, T., Liu, J., Mejia, A., Van 615 Loon, A., Aksoy, H., Di Baldassarre, G., Huang, Y., Mazvimavi, D., Rogger, M., Sivakumar, B., Bibikova, T., Castellarin, A., Chen, Y., Finger, D., Gelfan, A., Hannah, D. M., Hoekstra, A. Y., Li, H., Maskey, S., Mathevet, T., Mijic, A., Acuña, A. P., Polo, M. J., Rosales, V., Smith, P., Viglione, A., Srinivasan, V., Toth, E., van Nooyen, R. and Xia, J.: Panta Rhei 2013-2015: Global perspectives on hydrology, society and change, Hydrol. Sci. J., 61(7), 1174-1191, doi:10.1080/02626667.2016.1159308, 2016.

620 Melsen, L. A., Vos, J. and Boelens, R.: What is the role of the model in socio-hydrology? Discussion of "Prediction in a socio-hydrological world"*, Hydrol. Sci. J., 63(9), 1435-1443, doi:10.1080/02626667.2018.1499025, 2018.

Milly, P. C. D., Betancourt, J., Falkenmark, M., Hirsch, R. M., Zbigniew, W., Lettenmaier, D. P. and Stouffer, R. J.: Stationarity Is Dead: Whither Water Management ?, Science (80-. )., 319(February), 573$625574,2008$.

Nardi, F., Cudennec, C., Abrate, T., Allouch, C., Annis, A., Assumpção, T., Aubert, A. H., Bérod, D., Braccini, A. M., Buytaert, W., Dasgupta, A., Hannah, D. M., Mazzoleni, M., Polo, M. J., Sæbø, Ø., Seibert, J., Tauro, F., Teichert, F., Teutonico, R., Uhlenbrook, S., Wahrmann Vargas, C. and Grimaldi, S.: Citizens AND HYdrology (CANDHY): conceptualizing a transdisciplinary framework for citizen science 630 addressing hydrological challenges, Hydrol. Sci. J., 00(00), 1-18, doi:10.1080/02626667.2020.1849707, 2021.

Nie, M.: Drivers of Natural Resource-Based Political Conflict, Policy Sci., 36(3), 307-341, 2010. 
Nisbet, M. C.: Communicating Climate Change: Why Frames Matter for Public Engagement, Environ. Sci. Policy Sustain. Dev., 51(2), 12-23, doi:10.3200/ENVT.51.2.12-23, 2009. challenges under severe water scarcity: the Aculeo Lake process, Restor. Ecol., 29(2), 1-12, doi:10.1111/rec.13337, 2021.

Órdenes, M. and Díaz-Diego, J.: Cuando la mano de obra se subleva: estrategias terratenientes durante la reforma agraria chilena (1964-1973), Hist. Agrar. Rev. Agric. e Hist. Rural, (74), 201-230, doi:10.26882/histagrar.074e07o, 2018.

Pahl-Wostl, C.: Transitions towards adaptive management of water facing climate and global change, Water Resour. Manag., 21(1), 49-62, doi:10.1007/s11269-006-9040-4, 2006.

Pellizzoni, L.: Uncertainty and Participatory Democracy, Environ. Values, 12(2003), 195-224, 2012.

Renn, O.: Participatory processes for designing environmental policies, Land use policy, 23(1), 34-43, doi:10.1016/j.landusepol.2004.08.005, 2006.

Rice, J. L., Woodhouse, C. a. and Lukas, J. J.: Science and Decision Making: Water Management and TreeRing Data in the Western United States, JAWRA J. Am. Water Resour. Assoc., 45(5), 1248-1259, doi:10.1111/j.1752-1688.2009.00358.x, 2009.

Röckmann, C., Ulrich, C., Dreyer, M., Bell, E., Borodzicz, E., Haapasaari, P., Hauge, K. H., Howell, D.,

650 Mäntyniemi, S., Miller, D., Tserpes, G. and Pastoors, M.: The added value of participatory modelling in fisheries management - what has been learnt?, Mar. Policy, 36(5), 1072-1085, doi:10.1016/j.marpol.2012.02.027, 2012.

Rowe, G. and Frewer, L. J.: Public Participation Methods: A Framework for Evaluation, Sci. Technol. Human Values, 25(1), 3-29, doi:10.1177/016224390002500101, 2000.

655 Salter, J., Robinson, J. and Wiek, A.: Participatory methods of integrated assessment - A review, Wiley Interdiscip. Rev. Clim. Chang., 1(5), 697-717, doi:10.1002/wcc.73, 2010.

Scott, C. a., Varady, R. G., Meza, F., Montaña, E., de Raga, G. B., Luckman, B. and Martius, C.: SciencePolicy Dialogues for Water Security: Addressing Vulnerability and Adaptation to Global Change in the 
Arid Americas, Environ. Sci. Policy Sustain. Dev., 54(3), 30-42, doi:10.1080/00139157.2012.673454,

Somerville, R. C., Hassol, S. J., Somerville, R. C. J. and Hassol, S. J.: Communicating the science of climate change Communicating the science of climate change, , 64(10), doi:10.1063/PT.3.1296, 2011.

Stirling, A.: Analysis, participation and power: justification and closure in participatory multi-criteria analysis, Land use policy, 23(1), 95-107, doi:10.1016/j.landusepol.2004.08.010, 2006.

Varela-Ortega, C., Blanco-Gutierrez, I., Swartz, C., Downing, T. 2011. Balancing groundwater conservation and rural livelihoods under water and climate uncertainties: An integrated hydro-economic modeling framework. Global Environmental Change 21(2):604-619. https://www.sciencedirect.com/science/article/abs/pii/S095937801000

Voinov, A. and Bousquet, F.: Modelling with stakeholders, Environ. Model. Softw., 25(11), 1268-1281, doi:10.1016/j.envsoft.2010.03.007, 2010.

Voinov, A. and Gaddis, E. J. B.: Lessons for successful participatory watershed modeling: A perspective from modeling practitioners, Ecol. Modell., 216(2), 197-207, doi:10.1016/j.ecolmodel.2008.03.010, 2008. Webler, T., Tuler, S. and Dietz, T.: Modellers' and outreach professionals' views on the role of models in watershed management, Environ. Policy Gov., 21(6), 472-486, doi:10.1002/eet.587, 2011.

675 Wilson, R. S. and Arvai, J. L.: Policy Analysis Evaluating the Quality of Structured Environmental Management Decisions, Environ. Sci. Technol., 40(16), 4831-4837, 2006.

Wise, R. M., Fazey, I., Stafford Smith, M., Park, S. E., Eakin, H. C., Archer Van Garderen, E. R. M. and Campbell, B.: Reconceptualising adaptation to climate change as part of pathways of change and response, Glob. Environ. Chang., 28, 325-336, doi:10.1016/j.gloenvcha.2013.12.002, 2014.

680 Yates, D., Iwra, M. and Institute-boston, S. E.: Planning Model Part 2: Aiding Freshwater Ecosystem Service Evaluation, , 30(4), 501-512, 2005a.

Yates, D., Iwra, M. and Institute-boston, S. E.: WEAP21 - A Demand- , Priority- , and Preference-Driven Water Planning Model Part 1 : Model Characteristics, , 30(4), 487-500, 2005b. 